九州大学学術情報リポジトリ

Kyushu University Institutional Repository

\title{
Geographic Distribution and Habitat Differentiation in Diploid and Triploid Lilium lancifolium of South Korea
}

Kim, Jong Hwa

Department of Horticultural Science, Kangwon National University

Kyung, Hei Yong

Department of Horticultural Science, Kangwon National University

Choi, Yong Soon

Division of Biotechnology, Kangwon National University

Lee, Ju Kyung

Division of Bio-Resources Technology, Kangwon National University

他

https://doi.org/10.5109/9235

出版情報：九州大学大学院農学研究院紀要. 51 (2)，pp. 239-243，2006-10-27. Faculty of Agriculture, Kyushu University

バージョン :

権利関係 : 


\title{
Geographic Distribution and Habitat Differentiation in Diploid and Triploid Lilium lancifolium of South Korea
}

\author{
Jong Hwa KIM ${ }^{1 *}$, Hei Young KYUNG ${ }^{1}$, Yong Soon CHOI ${ }^{2}$, Ju Kyung $\mathrm{LEE}^{3}$, \\ Michikazu HIRAMATSU and Hiroshi OKUBO
}

\author{
Laboratory of Horticultural Science, Division of Agricultural Botany, \\ Department of Plant Resources, Faculty of Agriculture, \\ Kyushu University, Fukuoka 812-8581, Japan \\ (Received June 30, 2006 and accepted July 24, 2006)
}

\begin{abstract}
Habitats and geographic distribution were investigated for diploid and triploid L. lancifolium grown in islands and mainland areas covering a whole country of South Korea. Of 367 populations investigated, 185 (50.4\%) and 182 (49.6\%), respectively, were diploid and triploid populations. Diploid was intensively distributed only along western to southeastern coastal areas and islands, whereas triploid spread dominantly in inland areas of the Korean Peninsula. Diploid was specific to such seaside habitats as coastal cliffs or beaches but never to inland habitats. Triploid tended to prefer often-disturbed inland habitats such as roadsides, arable lands, hilly fields and riversides, though $23 \%$ of triploid individuals were growing in the coastal cliffs. The facts indicate that adaptability for disturbed habitats are crucial for the distribution range of each cytotype. Nonetheless, triploids were rarely found in coastal habitats within the diploid distribution range. Autotriploid formation from diploid ancestors under natural conditions may be suppressed by rareness of higher unreduced gamete productivity within the diploid species and/or by minority cytotype exclusion.
\end{abstract}

\section{INTRODUCTION}

Tiger lily (Lilium lancifolium) had been considered to be cytologically conspicuous species because it was the only triploid in the genus (Takenaka and Nagamatsu, 1930; Noda, 1966). Natural populations of diploid $L$. lancifolium were firstly found in the Tsushima Islands, Japanese western islands near the southern coast of the Korean Peninsula, by Noda (1978). Thereafter, it has been well confirmed that $L$. lancifolium is a polyploid complex involving both diploid and triploid forms (Noda, 1978, 1986, 1991).

Several reports (Wilson, 1925; Lightly, 1968; Noda, 1986; Noda and Lee, 1980; Song, 1997) mentioned the distribution of L. lancifolium in Korea, but little has been known about exact geographic distribution of each ploidy form.

Noda (1986) reported that the diploid form is confined to the southern part of the Korean Peninsula including Jejudo Island of South Korea and the Tsushima Islands of Japan, whereas the triploid form is widely distributed in East Asia. However, his description of the cytotype distribution in Korea stood on the investigation only on 11 sites of South Korea. Recently, Kim et al. (2005) found that 13 islands of the Bay of Kyunggi, the western region of South Korea, were inhabited by diploid alone in a high population density with up to 2000 reproductive individuals. Such dense and wide

1 Department of Horticultural Science, Kangwon National University, Chuncheon 200-701, Korea

2 Division of Biotechnology, Kangwon National University, Chuncheon 200-701, Korea

3 Division of Bio-resources Technology, Kangwon National University, Chuncheon 200-701, Korea

* Corresponding author (E-mail: jonghwa@kangwon.ac.kr) diploid distribution has never been reported in the other places except the Tsushima Islands. The facts suggest the wider distribution of diploid L. lancifolium in the Korean Peninsula.

We analyzed the cytotypes of a large number of $L$. lancifolium individuals collected from insular and the mainland populations covering an entire country in South Korea to understand the origin of triploid forms in nature.

\section{MATERIALS AND METHODS}

Three hundred and eighty seven individuals of $L$. lancifolium were collected from 367 populations of 66 different localities including 23 islands throughout the

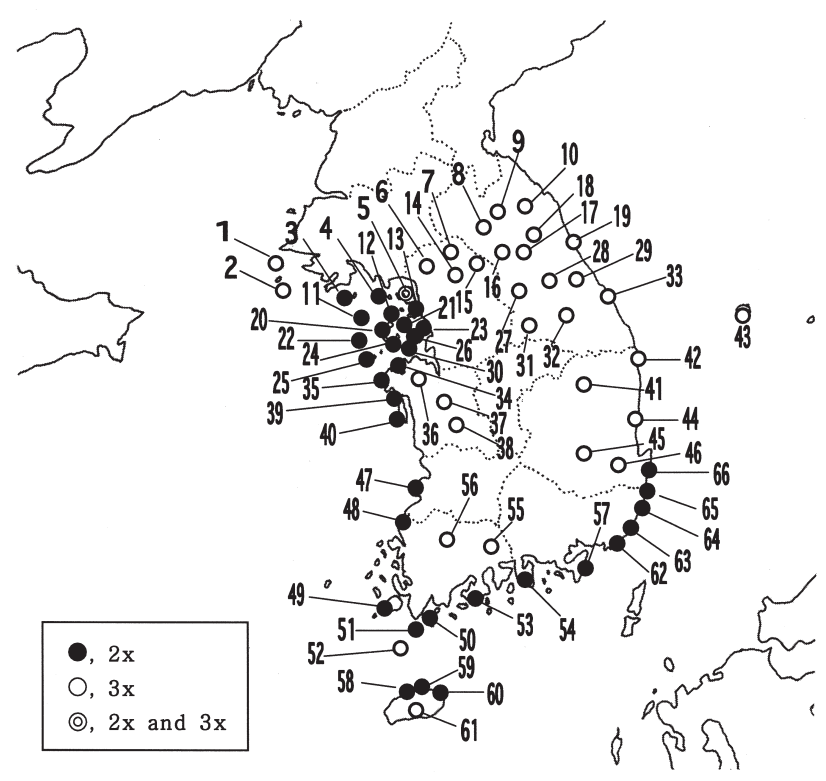

Fig. 1. Geographic distribution of diploid and triploid $L$. lancifolium in South Korea. 
Table 1. Localities, habitats, and ploidy forms of L. lancifolium populations found in South Korea

\begin{tabular}{|c|c|c|c|c|c|}
\hline $\begin{array}{l}\text { Site } \\
\text { No. }\end{array}$ & Locality & Habitat & $\begin{array}{l}\text { No. of } \\
\text { populations } \\
\text { found }\end{array}$ & $\begin{array}{c}\text { No. of } \\
\text { plants } \\
\text { observed }\end{array}$ & $\begin{array}{l}\text { Ploidy } \\
\text { form }\end{array}$ \\
\hline 1 & Incheon City, Backryungdo & Island, coastal cliff & 10 & 10 & $3 \mathrm{x}$ \\
\hline 2 & Incheon City, Sochungdo & Island, coastal cliff & 11 & 21 & $3 x$ \\
\hline 3 & Incheon City, Daiyeonpyungdo & Island, coastal cliff & 11 & 11 & $2 \mathrm{x}$ \\
\hline 4 & Incheon City, Suckmodo & Island, coastal cliff & 5 & 5 & $2 \mathrm{x}$ \\
\hline \multirow[t]{2}{*}{5} & Incheon City, Kanghwado & Island, coastal cliff & 8 & 8 & $2 \mathrm{x}$ \\
\hline & & Island, disturbed habitat & 6 & 6 & $3 x$ \\
\hline 6 & Kyunggido, Jucksung & Mainland, disturbed habitat & 3 & 3 & $3 \mathrm{x}$ \\
\hline 7 & Kyunggido, Yeonchun & Mainland, disturbed habitat & 4 & 4 & $3 x$ \\
\hline 8 & Gangwondo, Chulwon & Mainland, disturbed habitat & 14 & 14 & $3 x$ \\
\hline 9 & Gangwondo, Sangseo & Mainland, riverside & 11 & 11 & $3 x$ \\
\hline 10 & Gangwondo, Yanggu & Mainland, disturbed habitat & 7 & 7 & $3 x$ \\
\hline 11 & Incheon City, Achado & Island, coastal cliff & 19 & 19 & $2 x$ \\
\hline 12 & Incheon City, Yungjongdo & Island, coastal cliff & 7 & 7 & $2 x$ \\
\hline 13 & Incheon City, Songdo & Mainland, coastal cliff & 2 & 2 & $2 x$ \\
\hline 14 & Kyunggido, Pochun & Mainland, disturbed habitat & 7 & 7 & $3 x$ \\
\hline 15 & Kyunggido, Gapyung & Mainland, disturbed habitat & 3 & 3 & $3 x$ \\
\hline 16 & Gangwondo, Hanam & Mainland, riverside & 12 & 12 & $3 x$ \\
\hline \multirow[t]{2}{*}{17} & $\begin{array}{l}\text { Gangwondo, Chuncheon, } \\
\text { Seomyun }\end{array}$ & Mainland, riverside & 9 & 9 & $3 \mathrm{x}$ \\
\hline & & Mainland, disturbed habitat & 3 & 3 & $3 x$ \\
\hline \multirow[t]{2}{*}{18} & $\begin{array}{l}\text { Gangwondo, Chuncheon, } \\
\text { Dongmyun }\end{array}$ & Mainland, riverside & 7 & 7 & $3 \mathrm{x}$ \\
\hline & & Mainland, disturbed habitat & 4 & 4 & $3 x$ \\
\hline 19 & Gangwondo, Yangyang & Mainland, riverside & 4 & 4 & $3 x$ \\
\hline 20 & Incheon City, Eulwangdo & Island, coastal cliff & 4 & 4 & $2 \mathrm{x}$ \\
\hline \multirow[t]{2}{*}{21} & Incheon City, Mooeuido & Island, coastal cliff + beach & 3 & 3 & $2 \mathrm{x}$ \\
\hline & & Island, beach & 3 & 3 & $2 \mathrm{x}$ \\
\hline 22 & Incheon City, Deokjuckdo & Island, coastal cliff & 13 & 13 & $2 \mathrm{x}$ \\
\hline \multirow[t]{2}{*}{23} & Incheon City, Jawoldo & Island, coastal cliff & 8 & 8 & $2 \mathrm{x}$ \\
\hline & & Island, beach & 3 & 3 & $2 \mathrm{x}$ \\
\hline 24 & Incheon City, Youngheungdo & Island, beach & 4 & 4 & $2 \mathrm{x}$ \\
\hline 25 & Incheon City, Backado & Island, coastal cliff & 13 & 13 & $2 x$ \\
\hline 26 & Incheon City, Jangbongdo & Island, coastal cliff & 13 & 13 & $2 \mathrm{x}$ \\
\hline 27 & Gangwondo, Heongsung & Mainland, disturbed habitat & 3 & 3 & $3 \mathrm{x}$ \\
\hline 28 & Gangwondo, Hongchun & Mainland, disturbed habitat & 5 & 5 & $3 x$ \\
\hline 29 & Gangwondo, Pyungchang & Mainland, disturbed habitat & 7 & 7 & $3 \mathrm{x}$ \\
\hline 30 & $\begin{array}{l}\text { Choongchungnamdo, } \\
\text { Dainanjido }\end{array}$ & Island, coastal cliff & 3 & 3 & $2 \mathrm{x}$ \\
\hline 31 & Gangwondo, Yungwol & Mainland, riverside & 2 & 2 & $3 x$ \\
\hline 32 & Gangwondo, Jungseon & Mainland, riverside & 2 & 2 & $3 x$ \\
\hline 33 & Gangwondo, Samchuck & Mainland, coastal cliff & 3 & 3 & $3 \mathrm{x}$ \\
\hline 34 & $\begin{array}{l}\text { Choongchungnamdo, Taeahn, } \\
\text { Iwon }\end{array}$ & Mainland, coastal cliff & 3 & 3 & $2 \mathrm{x}$ \\
\hline 35 & $\begin{array}{l}\text { Choongchungnamdo, Taeahn, } \\
\text { Wonbook }\end{array}$ & Mainland, coastal cliff & 4 & 4 & $2 \mathrm{x}$ \\
\hline 36 & $\begin{array}{l}\text { Choongchungnamdo, Seosan, } \\
\text { Sungyeonmyun }\end{array}$ & Mainland, disturbed habitat & 4 & 4 & $3 \mathrm{x}$ \\
\hline 37 & $\begin{array}{l}\text { Choongchungnamdo, Yesan, } \\
\text { Yesanub }\end{array}$ & Mainland, disturbed habitat & 2 & 2 & $3 x$ \\
\hline 38 & Choongchungnamdo, Gongjoo & Mainland, disturbed habitat & 5 & 5 & $3 x$ \\
\hline 39 & $\begin{array}{l}\text { Choongchungnamdo, Taeahn, } \\
\text { Nammyun }\end{array}$ & Mainland, coastal cliff & 4 & 4 & $2 \mathrm{x}$ \\
\hline 40 & $\begin{array}{l}\text { Choongchungnamdo, Taeahn, } \\
\text { Anmyun }\end{array}$ & Island, coastal cliff & 3 & 13 & $2 \mathrm{x}$ \\
\hline 41 & Kyungsangbookdo, Andong & Mainland, riverside & 8 & 8 & $3 x$ \\
\hline 42 & Kyungsangbookdo, Uljin & Mainland, coastal cliff & 6 & 6 & $3 x$ \\
\hline 43 & Kyungsangbookdo, Urleungdo & Island, coastal cliff & 1 & 1 & $3 \mathrm{x}$ \\
\hline 44 & Kyungsangbookdo, Yungduck & Mainland, coastal cliff & 7 & 7 & $3 x$ \\
\hline 45 & Kyungsangbookdo, Yungcheon & Mainland, disturbed habitat & 2 & 2 & $3 x$ \\
\hline 46 & Kyungsangbookdo, Kyungjoo & Mainland, riverside & 3 & 3 & $3 \mathrm{x}$ \\
\hline 47 & Jeolabookdo, Booahn & Mainland, coastal cliff & 4 & 4 & $2 \mathrm{x}$ \\
\hline 48 & Jeolanamdo, Youngkwang & Mainland, coastal cliff & 1 & 1 & $2 \mathrm{x}$ \\
\hline 49 & Jeolanamdo, Jindo & Island, coastal cliff & 4 & 4 & $2 \mathrm{x}$ \\
\hline 50 & Jeolanamdo, Wando & Island, coastal cliff & 5 & 5 & $2 x$ \\
\hline 51 & Jeolanamdo, Bogildo & Island, coastal cliff & 1 & 1 & $2 x$ \\
\hline
\end{tabular}


Table 1. Continued

\begin{tabular}{|c|c|c|c|c|c|}
\hline $\begin{array}{l}\text { Site } \\
\text { No. }\end{array}$ & Locality & Habitat & $\begin{array}{l}\text { No. of } \\
\text { populations } \\
\text { found }\end{array}$ & $\begin{array}{c}\text { No. of } \\
\text { plants } \\
\text { observed }\end{array}$ & $\begin{array}{c}\text { Ploidy } \\
\text { form }\end{array}$ \\
\hline 52 & Jeolanamdo, Choojado & Island, coastal cliff & 3 & 5 & $3 x$ \\
\hline 53 & Jeolanamdo, Goheung & Mainland, coastal cliff & 4 & 4 & $2 x$ \\
\hline 54 & Jeolanamdo, Namhae & Mainland, coastal cliff & 3 & 3 & $2 \mathrm{x}$ \\
\hline 55 & Jeolanamdo, Sooncheon & Mainland, disturbed habitat & 2 & 2 & $3 x$ \\
\hline 56 & Jeolanamdo, Goorye & Mainland, disturbed habitat & 1 & 1 & $3 x$ \\
\hline 57 & Kyungsangnamdo, Geojedo & Island, coastal cliff & 3 & 3 & $2 x$ \\
\hline 58 & Jejudo, Aewol z & Island, coastal cliff & 3 & 3 & $2 \mathrm{x}$ \\
\hline 59 & Jejudo, Goojwa & Island, coastal cliff & 6 & 6 & $2 x$ \\
\hline 60 & Jejudo, Hwasoon & Island, coastal cliff & 2 & 2 & $2 \mathrm{x}$ \\
\hline 61 & Jejudo, RDA center & Mainland, disturbed habitat & 1 & 1 & $3 x$ \\
\hline 62 & Pusan, Gijanggun & Mainland, coastal cliff & 3 & 3 & $2 \mathrm{x}$ \\
\hline 63 & Pusan, Gijanggun & Mainland, coastal cliff & 1 & 1 & $2 x$ \\
\hline 64 & Ulsan, Uljoogun & Mainland, coastal cliff & 6 & 6 & $2 \mathrm{x}$ \\
\hline 65 & Ulsan, Bookgu & Mainland, coastal cliff & 4 & 4 & $2 x$ \\
\hline \multirow[t]{2}{*}{66} & Pohang, Gampo & Mainland, coastal cliff & 2 & 2 & $2 \mathrm{x}$ \\
\hline & Total & & 367 & 387 & \\
\hline
\end{tabular}

z Triploid was found by Song (1997), but not in this experiment.

whole country of South Korea (Fig. 1, Table 1). Number of individuals collected from each population was 1 to 21. A bulbil or bulb was sampled from each reproductive plant in summer and autumn seasons from 1998 to 2005. The populations geographically isolated at least more than $100 \mathrm{~m}$ distance from other populations were judged as independent populations. Habitats of the populations were grouped into four categories; that is, 1) coastal cliffs, 2) coastal beaches, 3) riversides, and 4) disturbed habitats often affected by human activities including roadsides, arable fields, graveyards and grassy hills.

The ploidy level was determined by counting chromosome number of root tip cells and/or measuring relative DNA content of leaf cells with a flow cytometer (Partec PA Ploidy Analyzer, Germany). Procedures of chromosome observation and flow cytometric analysis were previously reported (Kim et al., 2005).

\section{RESULTS}

\section{Geographic distribution of diploid and triploid $L$. lancifolium}

We found 367 populations of $L$. lancifolium throughout the country of South Korea. The localities and habitat description of the populations, and the ploidy forms detected for each population are shown in Table 1. Population frequencies were almost the same between the cytotypes with 185 (50.4\%) diploid and 182 (49.8\%) triploid populations (Table 2 ).

Diploid individuals were concentrated in the western (site Nos. 3-5, 11-12, 13, 20, 21-26, 30, 40) and southern (site Nos. 49-51, 59-60) islands and along western to southeastern coasts of the mainland (site Nos. 34-35, 39, 47-48, 53-54, 57, 62-66), but never found in inland areas (Fig. 1). Of 185 diploid populations, 138 (74.6\%) were found in islands and 47
(25.4\%) in the mainland (Table 2).

By contrast, triploid individuals were the representative cytotype in inland areas of the mainland of South Korea (Fig. 1). Inland individuals were more easily found in northern provinces than in southern provinces. Exceptionally, only in three sites (site Nos. 33, 42, 44) of the mainland, triploid was growing in coastal populations (Table 1).

Insular populations of the triploid were rather minority; 32 (17.6\%) of the 182 triploid populations were found only in six of 23 islands (Table 2). There were no diploid, but only triploid individuals in Backryungdo (site No. 1) and Sochungdo (site No. 2), the northernmost islands in the west coast, Urlengdo (site No. 43), an island in the east coast, and Choojado (site No. 52), a southern island (Table 1). Eight diploid and six triploid populations occupied Kanghwado (site No. 5), one of the nearest islands to the west coast, with close distance. One triploid population was found in the southern island, Jejudo, where diploid populations were rather dominant. Triploid plants in these islands set no capsules.

\section{Habitat differentiation between diploid and triploid $L$. lancifolium}

Diploid individuals persisted in the coastal habitats, whereas triploid individuals tended to prefer inland habitats often affected by human activities or on the riverside (Table 1). Even in the sites where the both cytotypes were located in a relatively close distance (Site No. 5), they never grew sympatrically in the same population; i.e., diploid individuals were growing on coastal cliffs, but triploid in the roadside.

Among 185 diploid populations, 175 (94.6\%) were observed on coastal cliffs (Table 2). These populations were growing in the narrow zones from $2-3 \mathrm{~m}$ above sea level to the margin of the forest and rarely found in the 
Table 2. Observation frequency of diploid and triploid L. lancifolium populations for four habitat types in South Korea

\begin{tabular}{|c|c|c|c|c|c|}
\hline \multirow{2}{*}{$\begin{array}{l}\text { Ploidy forms } \\
\text { and distribution area }\end{array}$} & \multicolumn{5}{|c|}{ No. of populations observed in the habitats classified below } \\
\hline & Coastal cliff & Beach & Riverside & $\begin{array}{l}\text { Disturbed } \\
\text { habitat }^{z}\end{array}$ & Total \\
\hline $2 \mathrm{x}$ in the mainland & 47 & 0 & 0 & 0 & 47 \\
\hline $2 \mathrm{x}$ in islands & 128 & 10 & 0 & 0 & 138 \\
\hline $2 \mathrm{x}$ total & 175 & 10 & 0 & 0 & 185 \\
\hline $3 \mathrm{x}$ in the mainland & 16 & 0 & 58 & 76 & 150 \\
\hline $3 \mathrm{x}$ in islands & 25 & 0 & 0 & 7 & 32 \\
\hline $3 x$ total & 41 & 0 & 58 & 83 & 182 \\
\hline
\end{tabular}

${ }^{2}$ Habitats often affected by human activities including roadsides, arable fields, graveyards and grassy hills.

forest. In islands, 10 (5.4\%) were growing on the beach. Among 182 triploid populations, 83 (45.6\%) were growing in such ruderal habitats as arable lands, roadsides, graveyards and hilly zones. Fifty-eight (31.9\%) populations were found on the riverside in inland areas. The remaining 41 (22.5\%) were growing in the habitats similar to those inhabited by diploid forms, namely, coastal cliffs.

\section{DISCUSSION}

Before the present study, the most detailed information on cytotype distribution of $L$. lancifolium has been recorded in Japan, where diploid forms were found only in the Tsushima Islands and Iki Island, the islands between Kyushu Island in Japan and Pusan in South Korea, but never in the other areas (Noda, 1978, 1986; Hiramatsu, unpublished data). Jugging from the previous and the present study in which no diploid was found in the whole inland areas, the east coastal areas, and the northernmost islands in the west coast, it is highly probable that geographic distribution of diploid $L$. lancifolium is restricted in western and southern coastal areas of the Korean Peninsula. The description of geographic distribution for diploid L. lancifolium in the present study is more precise than that previously reported (Noda, 1986; Kim et al., 2005).

Opposite to the limited distribution of diploid $L$. lancifolium, its triploid seems to maintain considerable wide distribution in Eastern Asia including the Japan Islands, the Korean Peninsula, the north-east district of China as shown in the present and previous studies by Noda (1986). A more widespread distribution of the polyploid than that of the ancestral diploids is a well-known, typical output phenomenon of success in plant polyploidy (Stebbins, 1950). Cytotype distribution data shown in the present study imply that triploid is adaptive to inland habitats often disturbed by human activities or floods, but diploid is not. Such ability specific to triploid could explain its widespread distribution.

Since no tetraploid Lilium species has been found under natural conditions so far, only diploid that can produce functional unreduced gametes could be the resource of triploid, and therefore, triploid individuals of early generations are expected to grow within or near their diploid progenitors. Only in three areas (Kanghwado, Choojado and Jejudo Island), however, triploid forms were parapatrically growing within the diploid distribution range.

Though it is difficult to explain why coexistence of the both cytotypes has not been detected for the moment, we can only propose two possible reasons. First, 'minority cytotype exclusion', a model of frequency-dependent selection against the newly formed rarer cytotype when two populations with different ploidy levels grow in sympatry (Levin, 1975), may work critically in populations densely dominated by diploid individuals. This hypothesis is consistent with the fact that triploids are growing dominantly on coastal cliffs where diploids are absent, as we confirmed in the several sites. Second, since variations in rate to develop functional unreduced gametes have been observed in many nonhybrid crop species (Bretagnolle and Thompson, 1995) and in interspecific hybrids of Lilium (Lim et al., 2001), frequency of autotriploid emergence may be significantly different among different diploid lineages of $L$. lancifolium. In order to answer which factor is attributable to the emergence of autotriploid in natural conditions, more precise investigations if both cytotypes grow in more close distance, if there is a close genetic relationship between such sympatric and parapatric cytotypes, and if production frequency of functional unreduced gametes is genotype-dependent are required.

Noda (1986) hypothesized from his cytological studies that the triploid $L$. lancifolium may be the allotriploid produced by 'interspecific' hybridization between a 'diploid' L. lancifolium and the taxonomically close 'diploid' species, L. maximowiczii. However, the possibility for allotriploids originated from the interspecific hybridization between these diploid species may be hardly accepted yet, because L. maximowiczii has never been found sympatrically and parapatrically with the 'diploid' L. lancifolium in previous (Noda, 1986) and our investigations (unpublished data). 


\section{REFERENCES}

Bretagnolle, F. and J. D. Thompson 1995 Gametes with the somatic chromosome number: mechanisms of their formation and role in the evolution of autopolyploid plants. New Phytol., 129: 1-22

Kim, J. H., Y. Xuan, M. Hiramastu and H. Okubo 2005 Natural habitats and geographic distribution of Lilium lancifolium in islands of the Bay of Kyunggi, Korea. J. Fac. Agr., Kyushu Univ., 50(2): 593-600

Levin, D. A. 1975 Minority cytotype exclusion in local plant populations. Taxon, 24: 35-43

Lightly, R. W. 1968 The lilies of Korea. Lily Year Book, Roy. Hort. Soc., 31: 31-39

Lim, K.-B., M. S. Ramanna, J. H. de Jong, E. Jacobsen and J. M. van Tuyl 2001 Indeterminate meiotic restitution (IMR): a novel type of meiotic nuclear restitution mechanism detected in interspecific lily hybrids by GISH. Theor. Appl. Genet., 103: 219-230

Noda, S. 1966 Cytogenetics on the origin of triploid lilies. I. Occurrence of binucleate cells in PMC and triploid variety. Bot. Mag. Tolyo, 84: 399-409

Noda, S. 1978 Chromosomes of diploid and triploid forms found in the natural populations of tiger lily in Tsushima. Bot. Mag. Tokyo, 91: 279-283
Noda, S. 1986 Cytogenetic behavior, chromosome differentiations, and geographic distribution in Lilium lancifolium (Liliaceae) Plant Species Biology, 1: 69-78

Noda, S. 1991 Chromosomal variation and evolution in the genus Lilium. In: "Chromosome Engineering in Plants: Genetics, Breeding, Evolution. Part B", ed. by T. Tsuchiya and P. K. Gupta, Elsevier, Amsterdam, pp. 507-524

Noda, S. and H. S. Lee 1980 Relationship between cytogenetic structure of three species in Liliaceae and human activities. In: "Reports for a Grant-in-Aid for Scientific Research from the Ministry of Education, Science, Sports and Culture of Japan, History on the successive changes of environments in Korea", pp. 33-55 (in Japanese)

Song N. H. 1997 Chromosomal differentiation and geographic distribution of Lilium lancifolium Thunberg native to Cheju island in Korea. Res. Sci. Math. Educ., Taegu Nat. Univ. Educ., 20: 93-105

Stebbins, G. L. 1950 Variation and Evolution in Plants. Columbia University Press, New York, pp. 342-379

Takenaka, Y. and T. Nagamatsu 1930 On the chromosomes of Lilium tigrinum Ker-Gawl. Bot. Mag. Tokyo, 44: 386-391 (in Japanese with English summary)

Wilson, E. H. 1925 The lilies of Eastern Asia. A monograph. Dulau \& Comp., London, p. 110 